\title{
Toplumcu Gerçekçi Yazar Kemal Bilbaşar'ın Cemo Adlı Eserinden Yansıyan Anadolu
}

\section{The Anatolia Reflected from the Work Cemo of Socialist Realist Author Bilbaşar}

\section{Elif Kaya*}

\section{Özet}

Toplumcu gerçekçilik, Marksist ideolojinin sanatçıya ve onun oluşturduğu esere yansımasıdır. Toplumcu gerçekçi eleştiri, edebiyatı yazıldığı toplumsal koşullar içinde ele alan ve toplumun ideolojisi içinde inceleyen bunu yaparken de estetik bir düzlem oluşturmayı amaçlayan bir kuramdır. Temeline insanı koyması, Marksizmle olan ilişkisi bu kuramın siyasal/ideolojik yönünü ön plana çıkarır.

1934 yılında, Sovyet Yazarlar Birinci Kongresi'nde resmi olarak kabul edilen ve aynı yıllarda Sovyet Rusya'da etkin olan akım, Türk edebiyatına da yeni soluk getirmiştir. Bu akımı yaşam felsefesi haline getirip eser veren bir yazar da Kemal Bilbaşar'dır.

Bu çalışmamızın ilk kısmında "Toplumcu gerçekçilik” genel özellikleri itibariyle ele alınmış, ikinci kısımda ise Kemal Bilbaşar’ın Cemo romanı toplum-

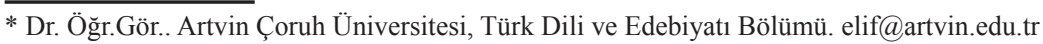


cu gerçekçilik bakımından değerlendirilmiş, toplumcu gerçekçi bakış açısıyla Anadolu'nun bir bölgesi gerçekçi bir düzlemde verilmeye çalışılmış ve yazarın toplumcu gerçekçi eğilimlerinin romanına nasıl yansıdığı üzerinde durulmuştur.

Anahtar sözcükler: toplumcu gerçekçilik, marksizm, Kemal Bilbaşar, Anadolu; Cemo

\begin{abstract}
Socialist realism is the reflection of the Marxist ideology on the author and his work. Socialist realistic criticism is a theory which deals with literature in the social conditions in which it is written, and examines it in the ideology of society and which aims to form an aesthetic platform. The fact that it grounds on human, its relation with Marxism brings the political/ideological feature of this theory into the forefront.

The current, which was officially recognized in 1934 at the First Congress of Soviet Writers and which was active in Soviet Russia in the same years, brought a breath of fresh air to the Turkish literature. Kemal Bilbaşar is an author who turns this current into a lifestyle and produces work.

In the first part of this study, 'Socialist realism' has been examined with its general features, in the second part the 'Cemo' novel of Kemal Bilbaşar has been examined in terms of socialist realism, a region of Anatolia has been given on a realistic platform from a socialist realism perspective and it has been focused on how the author's socialist realistic tendencies are reflected in his novel.
\end{abstract}

Keywords: socialist realism, marxism, Kemal Bilbaşar, Anatolia, Cemo

\title{
Giriş
}

Toplumcu gerçekçilik, temelini Marksizmden alan 20. yüzyılın etkin akımlarındandır. Marksizm kaynağından beslenen toplumcu gerçekçilik, siyasal ve ideolojik bir tavrı içinde barındırır; dolayısıyla Marksistler, feodal yapı, burjuva/aristokrat sınıfı, ezen kapitalist yapı karşısında, proletaryanın, devrimci emekçinin yanında olmuşlar ve ezilen halkla, sömürülen insanları savunmuşlardır. Bu açıdan bakıldığında Marksistler, kuramın dayandığı yansıtma ilkesi doğrultusunda gerçekçilik çizgisinde eserlerini vermişlerdir.

Toplumcu gerçekçi eleştiri, edebiyatı içinde oluştuğu tarih ve toplumla birlikte ele alır. Toplumun içinde bulunduğu şartları göz önünde bulunduran toplumcu gerçekçiler, ideolojileri de incelemeye ve sosyal yapının her unsuruna nüfuz etmeye çalışırlar.

Toplumcu gerçekçilik, topluma kılavuzluk eden, halkı yönlendiren, geniş kitlelere akıl veren iletiler sunma noktasında hedefini belirler. Toplumcu gerçekçiliği savunan yazarlar kendilerini yaşadıkları toplumun bir adım ötesinde görürler, bu nedenle de 
Çernişevski'nin dediği gibi gerçekçilik adına gerçeği yorumlamaya ve kişisel yargılarda bulunup sonuçlar üretmeye (Çubukçu, 1996; 27) çalışırlar. Halkı bilinçlendirmek isteyen sanatçılar bu amaçla eserlerinde olumlu kahramanlar, ideal tipler, olması gerekeni temsil eden, gerçekliği sezen durumlar yaratmaya çalışırlar.

"Yeni sanat önceki ve sonraki deneyimlerin oluşturduğu yeni eleştirel ilkede ve bu ilkenin gerçeğe yorumlanmasıdır. Yeni sanat, aynı zamanda hem ağacı hem ormanı gösteren ve onları niçin gösterdiğini bilen, 'sanat sanat içinden' mümkün olduğu kadar uzak, eylemci bir gerçekliği savunan, insana yardımcı olmak, yaşam yolunu aydınlatmak tutkusu içinde olan, yaşam yolunun anlamını hesaba katan ve bu yolculuğu yapan, kaçınılmaz, zorunlu bir yeni gerçekçiliktir" (Aragon,1994: 50). Aragon'un toplumsal gerçekçilik hakkındaki bu ifadeleri kuramın gerçekçilik anlayışını özetler. Toplumcu gerçekçi yazar, insanın yolunu aydınlatan kişi olarak edebiyatın içinde yer alır. Fakat Marx gerçeğin zaten devrimci olduğunu söyler. Bu açıdan bakıldığında toplumcu gerçekçi yazar, halka yol göstermek yerine var olan gerçeği ortaya koyması daha önemli olacaktır.

$\mathrm{Bu}$ noktada toplumcu gerçekçiler, mutlak gerçeğin 1şığıyla bugünün gerçeğini ele aldıklarını iddia ederler. Varoluş̧̧uluğun önemli kuramcılarından Albert Camus de onları bu açıdan eleştirir. Camus, sanatta belirli bir seçme ve eleme olduğunu düşünür, bu nedenle toplumcu gerçekçilerin konuyu gelecekteki gerçekte aramalarını ister. "Bugün var olan canlandırmak için, gelecektekini çizmek gerekir. Bir başka deyişle, sosyalist gerçekçiliğin konusu, daha henüz gerçekleşmemiş olandır. Ne büyük çelişki!? Son çözümlemede bu tür sanat, gerçekçilikten uzaklaştı̆ı ölçüde, sosyalist olur" (Gülgeçgil, 1976: 100). Albert Camus'nün düşüncelerini M. Kagan eleştirir ve toplumcu gerçekçiliğin gelecekte değil şimdi olan gerçeklikle bağlantısını savunur. "Sosyalist gerçekçilik gelecektekini değil, şimdi var olanı canlandırır. Ne var ki bu şimdi var olan durağan görüş açısından değil, gelecektekinin 1şığından ele alınır” (Gülgeçgil, 1976: 101).

Toplumcu gerçekçilik kendisinden önce var olan gerçekçilik anlayışından farklıdır. Burjuva toplumunda görülen sosyal bozuklukları ele aldığı için daha önceki realist anlayıştan keskin çizgilerle ayrılır.

"Geçen yüzyıldan beri burjuva toplumlarında bir gerçekçilik (realizm) hareketi ile karşılaşıyoruz. Söz gelimi, bu gerçekçi edebiyat günümüz burjuva toplumunda gördüğü toplumsal bozuklukları, toplumsal adaletsizliği ve eşitsizliği, toplumsal bozulmayı ele alır, onları eleştirir. Bundan ötürü bu gerçekçiliğe eleştirici gerçekçilik adı verilir. Oysa toplumcu gerçekçilik, yeni bir toplumun, bir sosyalist toplumun sanat anlayışını dile getirir. Eleştirilen toplum, burjuva toplumu yıkıldığına göre sanatın artık bozuk bir şeyi eleştirmesi de söz konusu değildir, tersine, sanat bu yeni toplumda, emekçi dayanışmasını, emekçi ahlakını sağlamlaştırmak ve bunun bir düzen içinde gelişmesini sağlamak görevini üzerine alacaktır. Sanat, bu anlamda sosyalist düzenin ve sosyalist ahlakın koruyucusu olacaktır" (Tunal1, 1979: 171-172).

Toplumcu gerçekçiler sanatı, kendi siyasi fikirlerine hizmet eden ideolojik bir çerçeveye dönüştürürler. Bütün varlığıyla içinde yaşadığı topluma maddi ve manevi bağları 
olan sanatçı bu nedenle bireysel ve sanatsal eğilimlerinden ziyade halkı yönlendiren ve ortak ülküde buluşturan politik ve ahlaki eserler ortaya koymak mecburiyetindedir. $\mathrm{Bu}$ ise sanatın özünü teşkil eden amacın dışında bir durumdur. E. Fischer bu durumda toplumcu gerçekçiliğin girdiği çıkmazı yanlış bulur ve doğru olanı yine kendisi ifade eder.

“Toplumcu sanatçı, emekçi sınıfının tarihsel görüş açısını benimser. Ama bu sanatçının işinde emekli sınıfını temsil eden her partinin ya da kişinin alacağı kararı ya da davranış1 doğru bulmakla görevli olduğu anlamına gelmez. Sanatçı, emekçi sınıfında, kapitalizmi yenecek, sınıfsız bir toplumu geliştirecek tek değilse bile, başlıca güç kaynağ1 olarak görür" ( Fischer, 1974: 159).

Tarihi ve felsefi yönden toplumcu gerçekçiliği değerlendiren Ahmet Oktay da, Toplumcu gerçekçiliği öncelikli olarak yazın ve sanat kuramından çok ortaya çıtığı Sovyet rejiminin bir uygulaması olduğu görüşündedir. Ahmet Oktay, toplumsal gerçekçiliğin karasız olduğunu düşünür. Oktay'a göre toplumsal gerçekçilik "Sanatı ekonomik temelin edilgin bir yansısı saymak gibi mekanik ve ideali imleyerek verili gerçeği aşabilecek bir tinsel güç görmek gibi romantik ve birbirleriyle çelişen iki ideolojik öğeyi birleştirmeyi çalışmasından doğar" (Oktay; 2008: 132).

Toplumcu gerçekçilik, uzun süre sanatın sadece belirli bir ideolojinin hizmetinde olduğu düşüncesi etrafında gelişir. Bu anlayış özellikle Sovyet Rusya'da bir zamanlar politikacıların dar parti anlayışı yönünde sanatçılara yaptıkları baskıdan kaynaklanır.

"Bütün olarak toplumcu sanat ve edebiyat, sanatçının ya da yazarın, emekçi sınıfın ve doğmakta olan toplumcu düzenin amaçlarıyla temelde anlamış olduğunu gösteriyor. $\mathrm{Bu}$ ayrıllğın sadece yeni anlatım biçimlerinin değil de yeni bir tutumun sonucu olduğu gerçeği Stalin zamanında yöneticilerin sanat işlerine sık sık karışmaları yüzünden gölgeleniyordu" (Fischer, 1974: 152). Fakat bu durum fazla sürmez. 25 Şubat 1956'da Sovyet Rusya'da düzenlenen 20. Kongre'den sonra Marksçı sanat teorisyenleri kuramda bir revizyona giderler. Sanatı daha özgür bırakan bu yenileşme çabaları, toplumcu gerçekçilere yeni bir anlam kazandırır.

Toplumcu gerçekçiler, neden-sonuç ilişkisini dikkate alarak eylemlerini açıklarlar. İşçi sınıfının düzene ve sosyal hayata başkaldırısı ise toplumcu gerçekçiliğin oluşumunu hızlandırır. Yani sosyalist gerçekçiliğin ortaya çıkmasında ve gelişmesinde sınıfsal farklılıklar büyük rol oynar. Proletaryanın sesi olan sanatçı, bu noktada toplumsal ve kültürel bir devrimci modeline girer.

"Bir yazarın, kendi görüş tarzını, mücadele etmekte ve zafere gitmekte olan işçi sınıfının görüş tarzıyla özdeşleştirmesi, hayattaki fenomenlere tümüyle ihtilalci proletaryanın sosyalist ruhu içinde cevap verebilmesi ve tarihsel gelişmenin gerçek tasarımı olarak komünizmi kabul etmesi gerekir" (Suchkov, 1978: 65). Suchkov'un bu düşüncelerine göre bir sanatçı, kapitalist bir ülkede ihtilalci işçi sınıfının görüş tarzını benimserse toplumcu gerçekçi yazar olur.

Toplumcu gerçekçiler sanatçıdan, gerçekliği ifade etmesini isterler. "Sanatçıdan gerçeğin, devrimden sonra gelişmesi içinde doğru ve soyut bir biçimde temsil edilmesini 
istemektedir. Bundan başka gerçeğin artistik bir biçimde doğru olarak ve tarihsel soyutluğu ile sunulması, işçilerin sosyalizm ruhu içinde ülküsel devrimi, eğitimiyle birlikte olması gerekmektedir" (Siniavski, 1967: 10).

Toplumsal gerçekçi yazar her şeyden önce etkin bir yazardır. Bu açıdan burjuva gerçekliğinden ayrılır. Dünya gerçeklerini yalnızca tanımak değil değiştirmek de ister. "Doğa ve toplum özde diyalektiktirler, içerdikleri çelişkilerle bir evrim geçirirler. Sosyalist gerçekçi bunu bilir ve bu damar atışını, bu zaman akışını hemen yakalar" (Lunaçarski, 1998: 84). Toplumcu gerçekçi hep amaca yönelir. İyi olanı bulmayı, göstermeyi amaç edinir. Ayrıca kötü, bozulmuş, düzensiz olanı da gösterip doğruyu bulmaya sevk eder.

Toplumcu gerçekçilerin sanat eserinde dayandıkları temelleri kısaca değerlendirmek gerekirse ilk olarak eserlerinde olumlu insan/kahraman tipi oluştururlar. Oluşturdukları bu tip idealize edilmiş, sömürülen halka örnek gösterilen kişidir. İkinci olarak sosyal bir taraf yani ezilen işçi sınıfının yanında yer alırlar. Açık bir şekilde taraf tutma, partizanlık söz konusudur. Yazar, ideolojik tavrını belirgin bir şekilde gösterir. Toplumcu gerçekçiliğin dayandığı diğer bir madde ise güdümlülüktür. İdeolojik tavrı olan sanatçı, eserinde bu ideolojiyi yansıtacak, ona gönderme yapacak metinler oluşturur. Ayrıca, yazar, halka, geniş kitlelere yöneldiği için hem folklor unsurlarına hem de destansı, halka ait bir söyleme başvurur. Bunun yanı sıra eserinde halkı yönlendirmek isteyen sanatçı estetik kaygı taşımaz. İçerik, biçimden önce gelir. Yazarın bakış açısında yurtseverlik de yine bir başka özelliktir. Bu yurtseverliğin içinde halka yöneliş vardır. Burjuvaya, feodal düzene, kapitalist sisteme de yine açıkça bir hedef gösterme, eleştirme ve karşı duruş söz konusudur. Böylece toplumcu gerçekçi anlayışta, olumlu tip yaratma, tarihsel iyimserlik, ulusallık, halkçı bir ifade, devrimci duruş, biçim-içerik uyumunun işlevsel hale dönüşü, burjuva sınıfı ile çatışma temel ilkeler haline gelir.

Çalışmanın konusunu teşkil eden Cemo romanı "toplumcu gerçekçi" yönüyle irdelenecek ve yukarıda sayılan maddeler ışığında değerlendirilmeye çalışılacaktır.

Anadolu'dan Hikâyeler, Cevizli Bahçe, Pazarlık, Pembe Kurt, Köyden Kentten, Ü̧ Buuutlu Hikâyeler, Irgatın Öfkesi, Kurbağa Çiftliği isimli hikâyeleri ve hikâyeleri ile aynı doğrultuda işlediği konuları ve hikâyelerinin biraz geliştirilmişi olan Denizin Çă̆lrlşı (1943), Ay Tutulduğu Gece (1961), Cemo (1966), Memo (1969), Yeşil Gölge (1970), Yonca Klz (1971), Başka Olur Ağaların Düğ̈̈nü (1972), Kölelik Dönemeci (1977), Bedoş (1980) ve Zühre Ninem (1981) adlı on romanın ${ }^{1}$ yazarı Kemal Bilbaşar (1910-1983) en çok da Cemo adlı romanı ile ün yapmıştır. Daha önce yayınladığı Çancının Karısı adlı hikâyesinin konu olarak genişletilmesi ile meydana gelen Cemo, yazara 1967 Türk Dil Kurumu Roman Ödülünü kazandırmıştır.

“Cemo romanını 'Çancının Karısı' adındaki büyük hikâyesine dayamış, HakkâriVan dolayları dağlık insanlarının yaşamlarını, yerli törelerin özelliklerini iyice belirterek tasvir etmiş. Onun, bu romanında en başarılı olan yanı, 'Cevizli Bahçe'deki hikâyelerinde görülen 'yerli renk gerçekçiliği’, yeniden güçlenerek ortaya çıkıyor” (Ünlü- Özcan, 1991: 370). 
Kemal Bilbaşar, eserlerinde Anadolu'nun ücra köşelerinde yaşanan toplumsal bozuklukları, onların lisanı ve hissiyatlarından hareketle vermiştir. Bunu yaparken de toplumcu gerçekçi çizgisini Anadolu gerçeği ile birleştirmeyi başarmıştır. Yazarın eserlerine baktığımızda toplumcu gerçekçiliğin ilkeleri etrafında yoğunlaştı̆ı̆ını görürüz. Özellikle halka inme, Anadolu'ya açılma noktasında içeriğin özünü, dili kullanarak vermeye çalışmıştır. Bilbaşar bu nedenle birçok eserinde estetikten çok içeriğe önem vermiştir. Bilbaşar, mesajı ön plana alıp estetik ifadeyi ötelemiş, eserlerinin içeriğini biçimden önce tutmuştur.

Sanat eseri, toplumun sosyo-ekonomik yapısı doğrultusunda gelişir. İki olgu da birbirini etkiler. Marksistler bu açıdan sanatçıyı, topluma karşı görevleri olan, toplumu yönlendiren bir yapı içinde ele alırlar. Sanatçı, halkın derdini bilmeli, çözüm üretmeli, halk ile bir olmalı, onları anlamalıdır. Halkı önceleyen bir sanat anlayışında ise estetik duruş, yazınsal özellikler doğal olarak ikinci plana atılır.

Bilbaşar da eserlerinde "hangi biçimde yazarsam düşüncemi halka daha iyi anlattrım" sorusundan yola çıkmış ve bu dikkatle eserlerini oluşturmuştur. Eserlerinde halkın bilgisi, anlayışı doğrultusunda ifadelere rastlamak mümkündür. Ayrıca meddah taklitlerine, halk masallarına ve hikâyelerine, halk deyişlerine yer vermiştir. Böylelikle eserinin daha rahat okunacağını ve eseri ile geleneğin birleşeceğini düşünmüştür.

Bilbaşar'ın eserlerine baktığımızda halk kültürü unsurlarını eserin biçimsel yapısını bozsa bile bol bol kullandığına şahit oluruz. Şiveli konuşmalar, halk hikâyesinden gelme yapılar, metinlerin içine serpiştirilmiş bir vaziyette karşımıza çıkar. Yazar, böylelikle okuyucunun aşina olduğu bilgi ve estetik birikim ile eserini daha iyi kavrayacağını düşünür. "Fikirde toplumcu, sanatta gerçekçi görüşe bağlı idim. Memleketimizin insanlarının dertlerini, toplum gerçeklerini ancak bu edebiyat tekniğiyle gün 1şığına çıkarmak ve onlara çözüm yolunu göstermek mümkün olacă̆ına inanlyordum" (Bilbaşar, 1967: 218-219).

Bilbaşar yine bir başka yazısında sanat kaygısı gütmediğini şöyle açıklar: "Bizim sanat anlayışımıza göre: Sanat'in toplumla ilişiği olması gerekir. Toplum etkisinde geniş bir halk edebiyatı olması gerek" (Bilbaşar, 1960: 19). Bilbaşar'a göre toplumu meydana getiren halktır. Onun problemlerini, onun isteklerini göz önünde tutmak sanatçının başlıca amacı olmalıdır. Bilbaşar bu şekilde mutluluk, eğlenme, övünme, gösteriş duygusu verecek bir süs edebiyatına da katılmayacağını ifade eder. Ve bu edebiyatın bir etkisi olacağına inanmaz.

Kemal Bilbaşar'ın, sanat anlayış1 estetik düzlemden uzak, halka yönelmiş, halkı anlatan, onların ıstıraplarını, sevinçlerini yansıtan bir tablo şeklindedir. Bilbaşar, hikâyeleri ve romanları ile toplumu bilinçlendirmek adına eserlerini kaleme almış, toplumcu gerçekçi çizgideki eserlerinde yerel motifleri kullanarak, edebiyatımıza farklı bir soluk getirmiştir. Birçok eserinde doğruyu gösterme, bilgilendirme, aydınlatma amacıyla toplumun kanayan yaralarına parmak basmış, eserleri aracıllğıyla sosyal yapıyı eleştirmiş, sorgulamış, ezenezilen çatışmasında, ezilenin yanında yer almış, sosyal hayat içinde ekonomik çıkarların 
ortaya koyduğu karakter çatışmalarını göstermeye çalışmıştır. Kısacası, yaşadığı dönemde Türk edebiyatının toplumcu yazarları içinde kendine yer edinmiştir.

\section{Sosyal sinıflar arasında ekonomik denge}

Toplumcu gerçekçi yazar, gerçek yaşamda gözlemlediği, şahit olduğu veya bizzat tecrübe ettiği olayları eserlerine aktarır. Ancak yazar, bahsi geçen bu türden bir olayı hikâyeleştirirken, Marksist görüşe göre yeniden kurgular ve akımın ilkelerine uygun bir biçimde kaleme alır. Toplumcu gerçekçi yazarlar, "edebî ürünlerini Marksizmin 'tezantitez' çatışması ilkesine dayanan, 'ezen-ezilen', 'burjuva-proletarya', 'sömüren-sömürülen', 'ağa-köylü’, ‘işçi-patron' gibi hep birbirinin düşmanı olarak telakki ettikleri sosyal sınıfların çatışması ve karşıtlığı üzerine kurarlar. Toplumsal olaylara diyalektik açıdan bakarlar. Ezen ve ezilen sınıfları temsil niteliğine sahip tipler üretirler ve eserlerini bu tiplerin mücadelesi üstüne kurarlar" (Çetin, 2004: 52).

Cemo adlı romanda kahramanlar, toplumcu gerçekçiliğin toplumsal yapıyı ele aldığ1 zıtlıklar çerçevesinde yani Marx'ın savunduğu maddeci diyalektiğe göre sınıflar arası yaşadıkları çatışmalar ile verilir ve ekonomik aynı zamanda mezhepler arası farklılıkların yarattığ́ ezen-ezilen, güçlü-güçsüz çatışması ekseninde iki farklı sınıf yaratılır. Bu iki sınıf yaşam mücadelesi verdikleri topraklar üzerinde sürekli derin bir çatışma içinde olurlar. Bu açıdan toplumsal yapı ekonomiye ve din odaklı ayrışımların sebep olduğu mezhepler arası çatışmaya bağlı olarak zıtlıklar içinde ezen-ezilen olarak meydana gelir.

Romanda ağa/şıh/seyit ile köylü karşılaşmasında sınıflar arasındaki çatışmanın temelinde ekonomik nedenler vardır. Toprağa, paraya, üretime dayalı çiftlik hayvanlarına sahip olan ağa/şıh/seyit, bölgesindeki gücü korumak emekçilere için her türlü zulmü yapar. Köylülerin yaşadığı durum insanî değerlerden uzaktır. Ağa/şı/heyit barbarca köylüyü maddi olarak ve işgücü yönünden sömürmektedir. Bilbaşar, Cemo'da toplumcu gerçekçi bir çizgide ezilen, sömürülen, sessiz bir çı̆̆lık olan köylünün yanındadır. Ezen, sömüren, köylüyü malı gibi kullanan ağa/şıh/seyite ise karşı tavır takınır. Yazar, ağa/şıh/ seyitin olumsuz özelliklerini ortaya koyarken bu mutlu azınlığın arkasındaki sömürge zihniyetini ve siyasi figürleri de eleştirmiştir. Köylüyü ezen bu sınıf ayrıca doğudaki ayaklanmalara destek veren Şeyh Sait'in adamları olup, Osmanlı'ya ve Gazi Paşaya da karşıdırlar. Yazar, ağayı kapitalist mantıkla işlerini gören ahlaksızlar olarak eleştirirken, onların siyasi olarak da yanlış tarafta olduklarını ifade ederek olumsuz yönlerini ortaya koyar. Böylelikle Marx’ın, “toplumsal konumu gereği proletarya, sınıflı toplumsal yapıyı sona erdirecek olan iradedir” (Marx; 1997, 204) ifadesinden yola çıkarak mutlu azınlığın yaşayacağı trajik sonu hazırlamış olur.

Cemo'da olay örgüsü romanın ana kahramanı Cemo'nun babası Cano’nun, Bey’inin istediği bir kızı kendisi için kaçırması ile başlar. Ağa kızının, kendi gibi bir ağaya gelin gitmesini planlarken bir köylü tarafindan kaçırılması roman boyunca sürecek olan çatışmanın temelini oluşturur. Romanın arka planını oluşturan Şeyh Sait ayaklanması ve köylü beylerin bu durumda iki gruba ayrılmaları da ekonomik çatışmayı besleyecek şekilde kurgulanır. Cano, Kevi ile evlendikten sonra uzun süre Cano’nun beyinden kaç- 
mak zorunda kalarak yaşarlar. Şeyh Sait ayaklanması başladığında ise köylüler ve ağalar iki gruba ayrılır. Büyük çoğunluğu “urum diyarında bir Osmanlı'nın” zalim padişahına karşı başkaldırıda bulunan paşanın tarafını tutar. Bazı ağalar ise Şeyh Sait'e destek olup onunla beraber devlete isyan ederler. Cano, yanına sığındığı Şıh Mahmut Ağa'nın tavsiyesi ile Şeyh Sait'e karşı savaşır. Onu ve çevresindekilerini öldürdükten sonra köyüne döndüğünde eşi Kevi'nin öldüğünü öğrenir. Kevi'nin ölümünden sonra Cano'nun kızı Cemo ile Zozana'ya dönmesi olay akışına yön verecek olan ve romandaki aksiyonu belirleyecek ekonomik ve sınıflar arası çatışma zeminini oluşturur. İlk çatışma da Şeyh Sait taraftarı olan köyün ağasının Cano'nun kızına talip olmasıyla meydana gelir. Kızının bir mal gibi satılmasına karşı olan Cano, ağanın bu isteğini geri çevirir. İstediği her şeye sahip olan ve köylü tarafından seçilmiş peygamber gibi hürmet gösterilen ağanın bu isteği karşısında olumsuz cevap alması hem köylü hem Cano'nun aleyhine gelişecek olaylar zincirini başlatır.

Şıh Sorikoğlu Cemo'yu almak için türlü hileye başvurur. Cano kızının satılık mal olmadığını, Kargadüzüne ilk kar düşende bileğine güvenen yiğidin kızını alacağını söyleyerek Sorikoğlu'nu küçük düşürür. Kargadüzüne ilk kar düştüğünde Cemo'ya talip olan yiğitler sırayla birbirleri ile dövüşürler. En son kalan yiğit ile de Cemo dövüşür. Tehlikeye karşı güçlü kuvvetli bir yiğit gibi yetişen Cemo kendisiyle dövüşen talibini yere serer. En son alana Çancı ustası Memo gelir. Memo'ya âşı olan genç kız onunla dövüşmeden atına biner ve oradan uzaklaşır. Böylelikle Sorikoğlu'na karşı Cano, Cemo ve köylü dışında, Sünni bir düşman eklenir. Bu olay ile ikinci ittifak oluşur. Sorikoğlu, Cano'nun köyünü satın alıp bütün köylüye işkence ederek intikamını almayı planlar. Sorikoğlu'nun köyü alma ihtirası, hilekârlığa varan entrikalara dayanır. Sorikoğlu Cano'nun köyünün sahibi İstanbul'da yaşayan avukatı kandırarak köyü satın almayı başarır. Memo ise köyü satın alan ağanın köyde yaşayan bütün insanları da satın aldığını bildiği için Sorikoğlu'nun, karısı Cemo'yu elinden alacağını tahmin eder. Okuma yazması olan ve askerlik yapan Memo, Gazi Paşa'nın bu tür durumlara firsat vermeyeceğini bildiğinden şehir merkezine inip yetkililiklerden yardım ister. Memo'nun devlet yetkililerinden yardım istemesi, köylü ve devletin Sorikoğlu ile karşılaşmalarına neden olur. Devlet burada iki şekilde çıkar. Memo'ya yardım eden Komutan Fahri Yarbay ve ondan çekinen yetkililer ilk önce köylüye arka çıkar. Dönemin diğer romanlarından farklı olarak ağa zulmünden kaçan köylü dağa çıkıp eşkıya olmak, ağaya karşı kendi haklarını savunmak yerine önce devletin kanunlarına sığınırlar. Fakat komutanın başka bir yere gitmesiyle kaymakam başta olmak üzere diğer yetkililer gücün tarafı olan Sorikoğlu'nun yanında yer alırlar. Devletin kaymakamı, köylünün yanında yer almak şöyle dursun, ağanın gücü ve parası karşısında köylüyü ezer ve ağalarının sözünden çıkması durumunda onlara hiç kimsenin sahip olmayacağını söyleyerek gözdağı verir. Kaymakam, Cano'ya "İ̧̧i yok da Osmanlı Paşası Zozana yaylasının kullarına hürlük dağıtan zagon mu çıkaracak? Yeni zagonlar tüm Osmanlı vatandaşı üzerinedir. Şıhların ağaların kullarıyla bir ilişiği yoktur." (Cemo, s. 211) diyerek tanınan hakları kabul etmek istemez. Aslında 
Cumhuriyet rejimi eşit haklar sunsa da her iki taraf -köylü ve ağa- bu durumu hazmedemezler. Ağa, sahip olduğu gücün elinden gitmesinden korkar; köylüler ise başlarında bir ağa olmadan yaşamayacaklarını düşünürler. Bu güne kadar "kul" gibi muamele gören köylüler, ağasız sudan çıkmış balığa döneceklerini zannederler.

Köylü bu endişelerinde haksız da değildir. Cano ve Memo'nun öncülük etmesiyle kendi obalarını kuran bir avuç köylü ağasız yaşamaya alışamaz. Cano ile birlikte Sorikoğlu zulmünden kaçan Velo Dayı'nın endişeli ifadeleri aslında devletin iktidar noktasında açıklarını da ortaya koyar."Ağasız nasıl ederik bunca insan? dedi. Komları neyle onarırık? Tohumu, unu, samanı, çifti kimden alırık? Önümüz kış. Ambarımızda bir avuç buğdayımız yok. Kış kıyamette ortada kalırık da acımızdan ölürük.” (Cemo, s.148) Velo dayının bu sözleri, aslında ağa yönetimine alışmış köy toplumunun ifadesidir. Köylü, toprağının, canının korunmasında devlete güvenemez. Köylü bugüne kadar da devletin onların zor durumunda yardım ettiklerini görmemiştir. Nitekim onlara yardım eden komutanın oradan ayrılmasıyla devleti temsil eden kaymakam köylünün aleyhine hareket edecektir.

Sorikoğlu, Cano'nun yaşadığı köyü satın almayı gurur meselesi yapmıştır. Köyün sahibi Şıh Mahmut öldükten sonra yerine avukat oğlu geçmiştir. Fakat avukat oğul yıllar önce İstanbul'a gitmiştir ve köye gelmemektedir. Köydeki işlerini takip edemeyen avukat, Sorikoğlu'nun teklifi karşısında memnun olur ve köyü satmaya karar verir. Köylü ve Cano Sorikoğlu'nun acımasız Şeyh Sait yanlısı bir ağa olduğunu bildiği için bu satılma işini elemle izler. Sorikoğlu'nun köyü satın alması Cano ve ondan yardım bekleyen birkaç köylünün bu zulme başkaldırmasına neden olacaktır. Sahip oldukları her şeyin köyün ağasına borçlu olduklarını bilen köylüler Sorikoğlu karşısında çıkmaza düşerler.

Osmanlı'nın kanunlarını bilen Memo, köylü adına askerde iyiliğini gördüğü komutanından yardım istemek için harekete geçer. Böylelikle köydeki yaşam, ağalık düzeni, illegal kanunlar, örfi hukuk karşısında devletin kanunları ve devletin adamları çatışmaya girer.

Kargadüzü köylüleri Sorikoğlu'na kul olmak isteyenler-istemeyenler olarak ikiye ayrılırlar. Memo ve Sorikoğlu'nun zulmünden kaçanlar için Çakalgediği isimli daha önce Şeyh Sait'e yardım ettikleri için sürülen köylülerin boşalttığı bir yurtluk bulunur ve köylüye tahsis edilir. Burayı ekip biçmek, hayvan almak, evleri tamir etmek ve malzeme almak için devletin bankası Ziraat Bankası'ndan ismini bilmedikleri biri adına kredi çekerler. Köylü şimdiye kadar ağaya borçlu olarak yaşamaktaydı; yeni düzende ise bir banka karşılığını vermedikleri takdirde sahip olduklarını almak koşuluyla köylüyü zor durumda bırakmaktadır. Köy halkı Sorikoğlu'na marabalık etmektense kendi köylerinde herkesin bir ağa gibi yaşamasını bütün isteklerinin üstünde tutarlar. Bu istek ve aynı ekonomik şartlar köylüyü bir arada tutan en önemli kuvvet olur. "Farklı toplumsal konumlanışlara sahip kesimlerin yoksullukta ortaklaşmalarının temel nedeni ise yarattıkları değere doğrudan ya da dolaylı olarak el konulması veya değer üretim sürecinin dışına itilmiş olmalarıdır” (Gün, 2013: 80). Uzun süre köylü ağasız nasıl yaşayacakları- 
n1, onları kimin muhafaza edeceğini, Sorikoğlu'na karşı canlarını nasıl koruyacaklarının hesabını yaparlar. Komutan Fahri Yarbay, beklentisi olmadan köylüye sahip çıkar. Fakat feodal kırıntısı Sorikoğlu para ve gücünü kullanarak komutanın sürülmesine sebep olur. Bu gidişat Çakalgediği halkı için felaket günlerinin başlangıcı olur. Sorikoğlu, bu durumdan faydalanarak köylünün maddi kazançlarını yağmalar. Kaymakamı rüşvet ile kendine bağlayan Sorikoğlu bankadan alınan kredinin de kefilidir. Borç ödeme vakti ellerinde olan malların Sorikoğlu'nun adamları tarafından yağmalanması, köylüyü zor durumda bırakır. Sorikoğlu borcunu ödeyemeyen köye, insanları ile beraber el koyar. Cemo'ya da sahip olmak isteyen Sorikoğlu aradaki engel Memo'yu pusu kurarak öldürmek ister. Çan satmak için Dersim pazarına giden Memo, köprü inşaatından dolayı Osmanlının onlara pusu kurduğunu düşünen korkmuş, sinmiş halk ile karşılaşır. Paralarını kendilerini korumak için tüfek/silah alarak harcayan halk, Çancı Memo'dan bir şey almaz. Memo, eli boş köyüne dönerken, Sorikoğlu'nun tuttuğu iki katil tarafından vurulur. Köylüyü ve Cemo'yu satın almak için önünde hiçbir engel kalmayan Sorikoğlu, köylüye verilen krediye kendi kefil olduğunu söyleyerek artık köyün kendi malı olduğunu ilan eder. Cemo ise uzun zaman sonra hamile kalmıştır. Sorikoğlu bunu öğrendiğinde genç kızı tekmelerle döverek çocuktan da kurtulmayı başarır. Artık Sorikoğlu, köye egemen güçtür. Parasını, varlığını ve gücünü kullanarak istediği her şeyi satan alan Sorikoğlu, devletin kanunlarını da para ile kendi lehine çevireceğinin örneğini sunar. Ona karşı durmak isteyen Cano ve arkadaşlarını ise kendisine saldırdığını söyleyerek hapsettirir. Kaymakamı para ile kandıran Sorikoğlu, köylüyü de gücünü kullanarak sindirmeye çalışır.

Cemo romanında iki anlatıcı vardır. Birinci kısım Cano tarafından kızı Cemo'nun nasıl yetiştiğini anlatmak için kurgulanmıştır. İkinci kısım ise Memo tarafından anlatılır. Bu noktada romanda başka bir sınıfsal çatışma ve ekonomik zıtlıklarla karşılaşırız. Asıl olay örgüsü ile sonradan bağlanacak bu kısımda Memo'nun Cemo'dan önce sevdiği kız ile yaşadığı trajik hikâye konu edinilir. Memo, bir şıh kızına âş̧ktır. Fakat sınıfsal çatışma iki sevgiliyi birbirinden ayırır. Şıh, kızını başka eşleri de olan yaşlı bir ağaya satar. Memo’yu ise intikamını almak için asker kaçağı diye ihbar eder. Memo askere gittiğinde onu romanın ilerleyen kısımlarında koruyup kollayan komutanı ile tanışır. Komutanın şerefine verilen bir şölende ise sevdiği kız Senem'in yaşlı ağa tarafında kullanıldığını görür.

Feodal ağa tipini temsil eden bu ağa bütün olumsuzlukları üstünde toplamıştır. Kötü, ahlaksız paragöz biri olan ağa, Senem'i dördüncü karısı olarak almıştır.

Para ve güç sahibi ağa, beğendiği genç kızları satın alıp gönlünü eğlendirdikten sonra onları bir kenara koyup, yeni genç kız arayışlarına girer. Ağa, Senem ile gönlünü eğledikten sonra yakın köylerde on üç yaşında başka bir genç kız alır. Senem'in kaderi ağanın diğer eşleri gibi bir kenara atılmakla sonuçlanır. Yazar arka planda kalsa da Marksizm'in bir başka yönü olan kadınların sosyal toplum içindeki yerlerine de böylece gündeme getirmiştir.

Ağa, Memo ve komutanını eğlendirmek için Senem'i çağırır ve bir çengi gibi oy- 
namasını ister. Senem ise âşık olduğu adamı karşısında görünce yardımcısı olan kadınla haber gönderip odasına çağırır. Memo'ya olan sevgisini itiraf eden Senem, şeyhten kaçıp onunla buluşmak için gün ve yer tayin eder. Ona yardım eden cariyesi ve eşi maddi imkânsızlıklardan dolayı çok sevdikleri Senem'i yüzüstü bırakırlar. Cariye ağadan aldığı yüklü para karşılığı hanımının yerini söyleyerek ona ihanet eder. Senem içeride eziyet ve baskı göreceği ağanın yanına dönerken, Memo onun kendini kurtarmak için suya atlayıp intihar ettiğini sanır.

Memo, Tunceli dönüşü vurulduğunda Senem'in sahip olduğu oba halk1 tarafindan bulunur. Onu kurtaran oba köylüsü Memo'nun kendine gelmesini beklemektedir. Memo iyileştikten sonra Senem'den başına gelenleri öğrenir. Üstelik Senem'in Memo'dan bir oğlu vardır. Ağalığa, şılığa karşı olan Memo bu köyün artık sahibi ve ağasıdır. Fakat Memo Çakalgediği'nde bıraktığı arkadaşları ve hamile eşini düşününce Senem'e geri geleceğini söyleyerek oradan ayrılır. Çakalgediğgi'ne vardığında ise her yerin yıkıldığı$\mathrm{n}$, tarumar edildiğini, erkeklerin bazılarının hapiste sağ kalan bazılarının ve kadınların Sorikoğlu'nun hizmetine girdiklerini öğrenir. Sorikoğlu, köylüye yardım eden kumandanın sürülmesinden sonra oluşan denetimsizlikten faydalanarak köylüyü ezmeye başlamıştır. Bu konuda en büyük yardımcısı ise kasabanın kaymakamıdır. Güç ve paranın esiri olmuş kaymakam, aldığı rüşvetle köylüyü yasalar karşısında kolayca kandırmıştır. Kaymakamın yaptığı usulsüzlükler ile köyü kendine bağlayan Sorikoğlu bunun şerefine bağ evinde bir eğlence düzenler. Memo ise intikam peşindedir. Karısına, köylüsüne yaptığı eziyetin karşıllı̆ını vermek için Sorikoğlu'nun evine baskın düzenler. Sorikoğlu ise Cemo'yu kaymakamı eğlendirmek için çengi gibi oynatmak isterken Memo evi basarak onları suçüstü yakalar. Sorikoğlu'nun ölmesi ise Cemo'nun gazabıyla olur. Kaymakam ise arka kapıdan kaçmak isterken uçuruma düşer ve ölür.

$\mathrm{Bu}$ açıdan Kemal Bilbaşar, toplumcu gerçekçiliğin dayandığı Marksist ideolojinin tesiriyle Cemo'da yaşanan günlük olayları, süregelen yaşamı, insanların hayatlarındaki rollerinin yerini açıklamada maddi nedenler koyduğunu, ekonomik durumların insanların sosyal ve bireysel hayatlarındaki yaşamlarının merkezi nokta olduğunu göstermeye çalışmıştır. Bu çatışmanın benzeri yine bu romanın devamı niteliğinde olan Memo'da da vardır. Toplumsal sorunların iktisadi ilişkilerin belirtilmesinde büyük rol oynadığını anlatan Memo'da ağa-köylü çatışmasını görürüz. Bu romanda Cemo'da olduğu gibi zengin bir ağa olan Şıh Persin ile fakir köylüyü temsil eden Memo'nun sınıfsal çatışması ele alınır.

Dolaysıyla Bilbaşar, toplumcu gerçekçi çizgide yazdığı bu romanlarda ekonomik olarak güçsüz olan halkı ezen, kapitalist, sömürü sistemini sürekli eleştirir. Kapitalist zihniyetin halkın geri kalmasında büyük rol oynadığını bilen yazar, sömüren ile gücü eşit görür ve halkın ezilmesinde bu gibi sınırsız güç sahiplerinin etkili olduğunu ifade eder. Kapitalist mantığı ortaya koyarken onlara karşı nasıl dik durulacağı noktasında çözüm önerisi göstermeye çalışır. Cemo ile ilgili verdiği bir röportajda bu hedefini açıkça ortaya koyar. 
“Cemo’yu daha çok Doğu Anadolu'nun yalnız İmparatorluk döneminde değil, Cumhuriyet çağında da horlanmış, ezilmiş, feodal toplum düzeninde bırakılmış halkına seslenmek, onları silkelemek, uyarmak amacı ile yazdım. Dünyalarını yoksulluk ve mahrumluklarla karartan feodal düzenin haksızlığını, acımasızlığını onlara somut olarak göstermek istedim. Henüz büyük çoğunluğu eğitimden yoksun, sözlü yazın döneminde yasayan bu çevrenin insanlarına, o yazının ağzı ile ve destan anlatısı ile seslenmek en doğru yol gibi geldi bana. Ama olay olarak halk öykülerini, masallarını değil, o tarih kesitindeki Doğu Anadolu yaşamını ele aldım. Yapıtın o çevre halkınca gördüğü ilgi, yanlış bir yol tutmadığımı gösterdi bana. Sanatçılarımız ve eleştirmenler bu anlatış biçimini beğenirler mi beğenmezler mi, umurumda değil. Su var ki, halk bilgisinin en canlı yanı olan bu hazineden yazınımız bugün de, yarın da hiç kuskusuz yararlanacaktır. Ferhat ile Şirin'ini dün Nâzım nasıl yorumlamışsa, yarın bir başka sanatçımız, o günkü dünya görüşü açısından, bu öyküyü daha farkl $\imath$ bir yorumla yeniden yaratabilecektir” (Bilbaşar, 1977: 3).

\section{Sanatın araç hâline dönüşsmesi}

Marksist görüşün temellendirdiği toplumcu gerçekçi anlayışta yazar, bilinçlidir ve eserinde bu bilinç gereği etkindir, yaşanılan olumsuzluklar karşısında halkı uyarmak ister. Nitekim topluluğun kuramcıları bu durumu şöyle ifade eder.

"Sanat estetik bir eğlendirici olmalı haz verip insanı oyalamalı, insanı yetiştirmeli, hayat dersi olmalı, bu iki işlevi birden yürüterek hem insanları eğlendirmeli, oyalama11; hem de insanlara öğretmeli hatta insanları yaşamın karanlıklarından kurtarıp ruhunu tanrıya doğru çevirmeli, ya da insanın gerçek varlık yasalarını tanımalı, en büyük amacı gerçek yaşamdan daha yetkin, ideal bir yaşam için modeller yaratmak olmalı; insanları bu ulaşılabilecek ya da ancak sanatta gerçekleştirilebilecek ideale doğru götürmeli” (Kağan, 1993: 272).

Kemal Bilbaşar, bu manada faal bir yazar olarak karşımıza çıkar. Kendisi bu durumu Cemo'yu yazma amacını anlattığı bir röportajında “yol, okul, su, sağlık nimetlerinden gereğince yararlandırılamamış, ortaçağ aşiret düzeyinden kurtarılıp bir türlü çağdaş uygarlık düzeyine kavuşturulamamış" olan Doğu Anadolu halkının yaşadığ 1 trajedinin sebeplerini anlatmak ve çözüm yollarını bulmak adına olduğunu ifade eder (Bilbaşar, 1972: 96).

Kemal Bilbaşar, eserlerinde olması gerekeni gösterip, sanatın faydacı yönünü vurgular. Sanatın faydacılığı noktasında güdümlü ve eğilimli anlayışı savunur. Sosyal hayat içinde ezilen, sömürülen, geniş halk kitlelerinin arkasında olur. Onları bu durumdan çıkaracak ekonomik planlar, sosyal programlar yapar.

Cemo adlı romanda kişiler kandırılan/kandıran, zıtlığı ve çatışması ekseninde iki farklı statüde yer alırlar ve bu sınıfların ayrışmasında en büyük etken ekonomik olarak zengin-fakir ayrımıdır. Romanda Bilbaşar, toplumcu gerçekçi yazar kimliği ile doğrudan 
ezilen sömürülen geniş halk kitlelerini anlatmaya çalışmış ve ekonomik çıkar çatışmasında parayı elinde bulunduran ağa/şeyh/seyitleri kötü, ezilen, sömürülen halkı ise iyinin tarafı olarak belirlemiştir. Toprak sahibi olan zenginlerin oluşturduğu ağalar, kapitalist mantığın bütün olumsuz yanlarını üzerlerinde taşırlar.

Güç noktasında oluşan zengin-fakir veya iyi-kötü sınıflandırılmasında, köylüyü kendi hizmetine alıp kullanmak isteyen Sorikoğlu ve ona yardım eden marabaları, yine çıkarları doğrultusunda rüşvet alan kaymakam kötüleri; köyde kendi çalışıp kendi ekmeğini kazanmak isteyen, çalıştıkları kadar hak iddia eden Cemo, Memo, Cano diğer köylüler iyi olanları temsil eder. Yazar bu iki sınıf arasındaki ekonomik çatışmayı bölgenin hassasiyetlerini düşünerek oldukça gerçekçi bir düzlemde vermeyi amaçlamıştır. Böylece kapitalist/sömürücü mantığın bir bölge halkı üzerindeki olumsuz etkilerini göstermeyi başarmıştır. Güçlü, kuvvetli ve çalışkan halk başlarında bir şıh olmadan nasıl yaşayacakları korkusundan, cahilliklerinden, geri kalmışlılarından ve dahası saf ve iyi niyetli olduklarından, hem bazı devlet adamları hem de köyün ağası tarafindan ezilirler, şiddet görürler ve köylerinden yurtlarından sürülecek kadar mağdur olurlar. Bilbaşar olayları oluşturan vaka örgüsü ve romanda yer alan kahramanlar ile oluşturduğu çatışmada kapitalist sınıfın sömürücü/ezen yönünü roman boyunca bize anlatsa da romanın sonunda ezilen sınıfın başarısını ortaya koyar.

Daha önce de belirtildiği gibi toplumcu gerçekçi yazar, sanatı halkın aydınlanması için araç olarak görür ve sanatta yan tutarak emekçi sınıfının yanında yer alır. Sanat kaygısından uzak, sanatı araç olarak kullanmak, sanatı ideolojik fikirleri doğrultusunda topluma yön vermek toplumcu gerçekçilerin amaçları arasındadır.

Toplumsal gerçekçiliğgin ideolojik yapısını oluşturan Marx, sanatçının özgürlüğünden yanadır. Maddi kaygılarla bile yazmasını doğru bulmaz. "Yazar çalışmalarını hiçbir zaman bir araç olarak görmez. Bu çalışmalar kendi içlerinde birer amaçtır" (Marx, 1968: 316).

Fakat Marx'ın bu görüşü Marksist anlayışı dikkate alan sanatçılar tarafından benimsenmez. Eserlerinde bir gaye/amaç güden yazarlar, bu doğrultuda eserler vermişlerdir. Açıkçası çoğunda bu anlayışın sonucu olarak belirgin bir şekilde ideolojik fikir çerçevesinde örülü metinler ortaya çıkmıştır. Sovyet yazar ve politikacı Jdanov, siyasî yapılanmalarda sanatın gücünden yararlanılacağı kanısındadır. Jdanov'dan önce Engels'in de bu konuda yazıları ve fikirleri vardır ve Engels, sanatta güdümlülük ve taraf tutmanın ne derece olduğunu yapıtlarında ifade eder. Jdanov'un göre sanat eserinin, halkın sorunlarını ifade etmesi onu doğrudan siyaset ile ilişkili hâle getirmiştir.

“...edebiyat eserinin başkahramanları, canla başla yeni hayatı inşa edenlerdir; yani, erkek ve kadın isçiler, erkek ve kadın kolhozcular, Parti üyeleri, yöneticiler,; mühendisler, genç komünistler, genç öncülerdir. Sovyet edebiyatının başlıca tipleri ve esas kahramanları iste bunlardır. Coşkunluk ve kahramanlık tutkusu tipleri ve esas kahramanları işte bunlardır. Coşkunluk ve kahramanlık tutkusu içgüdü biçiminde değildir. Edebiyatımız özünde iyimserdir, çünkü ilerleyen sınıfın, proletaryanın edebiyatıdır. 
Sovyet edebiyatının gücü, yeni bir davaya, sosyalist inşa davasına hizmet etmesinden gelmektedir" (Jdanov, 1977: 17).

$\mathrm{Bu}$ açıdan, Bilbaşar sanatın faydacı yönüne önem vererek emekçi sınıfına yönelir, geniş halk kitlelerini bilgilendirecek, onlara rehber olacak bir edebiyatın peşinde koşar. Kendini halkçı bir yazar olarak ifade eden Bilbaşar, emekçi/ezilen/köylü sınıfına ulaşmak için de onların diline/seviyesine yönelmek gerektiğini düşünür.

“1961'de emekli olup kısa bir süre politikayla uğraşmak zorunluğunu, halkçı bir yazar sorumluluğuyla kabullenerek, köy köy dolaştığım aylarda şunu fark ettim: Okumuş - yazmışları çok az olan köyler ve kasabalar halkı henüz sözlü edebiyat ortamında yaşamaktadırlar. Şehirli olan bizlerin en yalın bir dille anlattığımız nesnelerden bir şey anlamamaktadırlar. Aramızda köyden yetişmiş, köylü diyalektini rahatlıkla kullanan bir konuşmacımızı anlayışla izlediklerini görünce, halkçı bir yazarın, sözlü edebiyat ortamında yaşayan geniş halk topluluğuna ancak masal ve destan dilini kullanarak yaklaşabileceğini, içinde bulunduğumuz ekonomik, sosyal ve siyasal bunalımlar ve onların çözüm yollarını ancak bu araç ile anlatılabileceğini sezdim. Böylece 1963'te Cemo denemesine giriştim” (Bilbaşar, 1971: 6).

Bilbaşar bu görüşleriyle sanatında duracağı noktayı bildirmiş ve çizgisini sanatı faydacı bir anlayışla kurguladığını göstermiştir.

Bilbaşar, bazı eserlerinde de aynı şekilde toplumcu ve sanata görevci bir anlayışla yaklaşır. Yazar'ın, Ay Tutulduğu Gece, Memo, Yeşil Gölge, Yonca Kız, Başka Olur A ğaların Dügünü isimli romanlarında toplumsal yapıyı bozan olumsuz olayların üzerine gittiği görülür. Özellikle Cemo'nun devamı niteliğinde olan Memo'da ve yine bazı hikâyelerinde köy yaşantısında karşımıza çıkan kapitalist düzenden hareketle ezen-ezilen çatışmasında tarafını ortaya koyarak iyilerin yanında olduğunu ifade eder. Eserlerinde ezilen sınıfın kurtarıcı olarak gördüğü seçilen aydınlanmış kişi, sömürülen sınıfı arkasına alarak iyiyi/doğruyu bulmalarında onlara rehber kişi olur. Yazar, sosyal hayat içinde kötü insanlar ve kötü olaylar karşısında olumlu çizdiği kahramanların başarısıyla eserlerinde tezini de ortaya koyar. Böylelikle yapılan kötülükler karşısında her zaman iyilerin galip geleceği bilincini uyandırmaya çalışır.

Bilbaşar, Cemo'yu yazma amacının, “horlanmış, ezilmiş, feodal toplum düzeninde bırakılmış halkına seslenmek, onları silkelemek, uyarmak amacı” olduğunu belirtir (Bilbaşar, 1971:3).

\section{Anadolu köylüsüne bakış}

Edebiyat alanında verilen eserlerin hedefinde okuyucu kitlesi vardır. Edebî eser, okuyanın ruhu önünde akıp giden bir metindir. Bu nedenle yazar iletisini ve iletme şeklini iyi seçmelidir. Yazarın iletisi, alıcı ile bütünleşecek güçte ve orantıda olmalıdır. "Her edebiyat olayı, özellikle boyutça önemli ve içerikçe zengin olanlar, kitlelere ulaşacak 
biçimde düzenlenmek ve yapılanmak zorundadır" (Lunaçarski, 1998: 40).

Kemal Bilbaşar toplumcu gerçekçi bir sanat anlayışına sahip olmasından dolayı halka yönelmeyi amaç edinmiştir. Romanı yazmaya 1945 yılında karar verdiğini belirten yazar, yine o tarihlerde devletin yaptığı toprak reformu kanunundan etkilendiğini ifade eder. Eserleri ile Doğu Anadolu'nun geri kalmışlığına bir çözüm yolu bulmaya çalışmak yazarın amaçlarının başında gelir.

Meclisin yaptığı çalışmaları göz önünde bulunduran yazar, kapitalist düzende köylü-ağa çatışmasının kaçınılmaz bir durum olduğunu görür. Bu nedenle yazar, geniş halk kitlelerinin temsilciliğini yapmış; eserlerinde büyük oranda ezilen/sömürülen halkın hayatını toplumcu gerçekçi havada yansıtmıştır.

Yazar, özellikle kitlelerin anlayacağı bir dil, bir ifade biçimi kullanarak herkese ulaşmayı hedeflemiş̧ir. Fakat dil konusunda kahramanlarını şiveli konuşturması döneminde birçok eleştiriye sebep olmuştur. Amacı geniş halk kitlelerine ulaşmak olan yazar, yapılan eleştirilerin yersiz olduğunu savunur.

Cemo romanında Bilbaşar, o günkü Türkiye'nin Güney ve Doğu bölgesi halkını ilgilendiren konular işlemiştir. Oluşturduğu kahramanlar Cemo ve özellikle Memo'nun korkusuzca ağadan intikam alma hırs1, ona inanan köylüleri peşinden sürüklemiştir. Memo, romanda ağa zulmünden kaçan halk kitlesini bir hareket haline getirmiş, sonunda da bu hareketi Memo açısından haklı bir sonuca bağlamıştır.

Toplumcu gerçekçiler halk kitlelerinin hareketlerini eserlerine taşırlar. Bu nedenle de yan kahramanlar hatta asli kahramanlar bağlı oldukları kitle/köy/soy ile anılırlar. Cemo'da geniş halk kitleleri bulundukları mekân ismiyle değerlendirilmiş olsa da asli kahramanlar isimleri ile anılmıştır. Romanda köylülerden isim olarak belirtilenler yaşadıkları mekân ile anıldıkları görülür. Örneğin Zozana Halkı, Çakalgediği'nde yaşayan köylüler vs.

İsmiyle anılanlar kötü ve iyi olma noktasında çatışma oluşturan tiplerdir. Örneğin Cemo, Cano, Memo, Sorikoğlu vs.

Romanda toplumcu gerçekçi çizgide yazılan çoğu romanda göreceğimiz geniş halk kitleleri ve ferdi olarak ön plan çıkmayan kişilerin aksine burada bireysel tanıtılan kahramanlar vardır. Bu yazarın kendi üslup anlayışından kaynaklanır. Romanda ikinci derecede kalmış birçok kahraman da ayrıntılı olarak tanıtılmıştır. Örneğin Memo'nun dayısı, yengesi, Memo'ya destek olan köylüler vs.

\section{Anadolu'nun bir köşesinde ülküleştirilmiş kişiler}

Toplumcu gerçekçilik, toplumun toprağında gelişen bir kuramdır. Bu açıdan sosyal düzen ve yapı arasındaki çatışmayı göstermek yerine bu çatışmayı çözecek, ortadan kaldıracak, kahramanların yetişmesine olanak sağlayan bir yapı kurar.

"Toplumcu gerçekçilikte kahraman ülküleştirilmez, içinde bulunduğu toplumsal koşullar ve ilişkiler içinde ele alınır. Ancak bu koşullar ve ilişkileri kişiliğini güçlendirme 
yönünde değiştirmeye savaşır. Kendi kişisel çıkarlarını toplumsal çıkarlarla bütünleştirmiş bir kişidir o. Terimsel bir adlandırmayla söyleyelim: Olumlu kahramandır. 'Olumlu kahramanın güzelliği, sadece belirli ideal nitelikleriyle ortaya çıkmaz, bu niteliklerin iç çatışma ile biçimlenişi, bu niteliklerin pekişmesini engelleyecek her şeyi alt eden sağlam, ilerici güçlerin ve eğilimlerin zaferi ile kahramanın güzelliği anlatıma kavuşur.' Öyle ki kahramanın bu gelişim süreci, okuyucuyu etkileyecek, onun da bu kahraman gibi bir gelişim gösterebileceği düşüncesi okuyucuda oluşacaktır" (Özdemir, 1981: 117).

Toplumcu gerçekçi akımın temelini oluşturan "toplumsal düzenle çatışma" ve "toplumu daha iyiye ulaştırma" düşünceleri, Kemal Bilbaşar'ın eserlerinin doğal bir çıkış noktasıdır. Yazar bu yüzden, eserlerinde oluşturduğu "ezilen halk"ın karşısına "ezen güç"leri daima yerleştirmiştir. Böylece köylü/ağa; köylü/bürokrat; fakir/zengin; zengin/ bürokrat tipleri arasındaki çatışma -özellikle de sınıfsal farklılıklar- Kemal Bilbaşar'ın eserlerinin ana yapısını oluşturur. Yazar, sosyal bozukluğu ortadan kaldırmak için de güçlü olanın karşısına hep bir olumlu/olması gereken tip çizmiştir.

"Politik erdemin mükemmel bir temsilcisi olarak okurda sayg1 uyandiracak, okurun gıpta ederek benzemeye çalışacağı bir örnek olacak; şimdiki durum ile gelecek arasında bir bağ kurarak sosyalizmin başarılabileceğini gösterecek. Romanlarda bu tip, kendini görevine adamış, nefsine hâkim ve güçlü bir kişidir. Halk çok acı çekmiş, ama kendi başına çıkar yolu kestirememektedir; eğitime, bir yol göstericiye, bir lidere muhtaçtır. Olumlu kahraman karşılaştı̆̆ türlü güçlükleri yener, yardım etmek istediği insanlar içinde, düştüğü yalnızlığa katlanarak tarihin kendisine verdiği görevi yerine getirir" (Moran, 2004: 61).

Kemal Bilbaşar romanlarında ve onların alt yapısını oluşturan hikâyelerinde sanatsal söylemini arka plana atıp ideolojik ya da toplumsal görüşünü gösteren ifadeler ile ön plana çıkar; böylelikle toplumsal yapıyı irdeler, toplumsal yapı içeresindeki siyasal-dinisosyal durumu bozan durumlar üzerinde çıkarımda bulunur.

Bilbaşar, eserlerinde işlediği konular ile kişiler arasında paralellik vardır. Yazar, toplumcu geçekçi hassasiyetiyle ele aldığı eserlerinde kişileri, anlatmak istediği konu için bir araç olarak kullanır.

"Bir sanatkâr için hassaten muayyen bir konuyu işleyen diye bir şey yoktur. Hassaten bir konuyu işlemeye kalkan bir sanatkâr bir dâvanın adamı olarak yazı yazar. O zaman kendi zümresinden olmayanları kötüler. Bir kısım insanlar kötülüyor diye bazı konulara el atmayacak kadar cesaretsiz olan kimseler sanatkâr sayılmaz. Çünkü hakiki sanat adamı inandığ iyi, doğru ve güzeli anlatmakla mükelleftir. Sanatkârın konusu insan olduğuna göre, insanların bütün meseleleri sanatkârın meseleleridir” (Baydar, 1960: 53).

Toplumcu gerçekçi kuramı dikkate alarak eserlerini oluşturan Bilbaşar'ın kişilerinin tek yönlü olduğu ve psikolojik derinliklerinin olmadıkları görülür. Sonuca yönelik bir 
anlatımı tercih eden ve eserlerinde ezen-sömürülen halkın sesi olmaya çalışan yazarın bu nedenle özellikle yan karakterleri yazarın eğilimlerini ifade eden kişiler olmanın ötesine geçmez. Kişiler o dönemde karşımıza çıkacak herhangi birini temsil eden tiplerdir. Olay örgüsü içinde özellikle asli karakter dışında kalan kahramanlar yapması gereken görevi yerine getiren, düz, eserin tezinde yer alan iyi ya da kötü durumu sergileyen kişilerdir. Yazarın, toplumcu gerçekçi hassasiyetle ele aldığı diğer roman ve hikâyelerinde de bu tür düz, mekanik kahramanlarla karşılaşmaktayız.

Cemo'daki kişiler, temsil ettikleri özelliklerini ortaya koymaları dışında farklı bir değer taşımazlar. Kişilerin psikolojisine de yeterince yer verilmemiştir. Psikoloji bir yana Cemo, Senem, Kevi gibi istenilen arzu duyulan kadınlar hariç kahramanların fiziki özellikleri üzerinde de pek durulmamıştır. Fakat asli karakterler gerçek ve direnen tipler olarak mülkiyet teması etrafında oluşturmuştur.

Romanda yer alan köylüler ve ağa/şeyh/seyit gibi onları sömüren tipler de düz tiplerdir. Köylüler saf, cahil ve yarı tanrı gibi gördükleri ağalarının sözleri dışına çıkmayan, hayat hakkında hiçbir tasarrufları olmayan tiplerdir. Bu yönleriyle skolastik düşünceyi temsil ederler. Romanda yer alan "Cano, Cemo, Memo, Komutan Fahri Bey, Kaymakam, Ağa Sorikoğlu ortaçağ kaynaklı sorunların 1925'lerdeki özneleri durumundadır” (Kurdakul, 1987: 529).

Ağa/şeyh/seyit ise kendi hükümranlıklarını kuran, istediği her işi yapmayı kendinde hak gören feodal tipini temsil eder. Bu iki sınıf, romanda Türkiye'nin 1925 yıllarında özellikle köy gibi kırsal kesimlerinde yaşanan sınıflar arası çatışmayı göz önüne serer. Romanın diğer kahramanları yardımcı kişiler olarak karşımıza çıkan yarbay ve kaymakam vekili de bu sınıfsal çatışmaya taraf olan tiplerdir. Yarbay, köylüye yardım eden iyi tipin temsilcisiyken, kaymakam vekili, aldığı rüşvetle zengin ağanın maşası olan kötü tipi temsil eder.

Kahraman noktasında ayrıca toplumcu gerçekçiler eserlerinde iyi olanı savunur ve taraf tutarlar. Hem idealist tip oluşturma hem de bu tip ile iyi olanı savunma, yazarın açıkça bu kişinin yanında yer aldığı mesajını verir. Toplumcu gerçekçiler bu noktada edebiyatın halkçı, partizan, devrimci ve taraflı olması gerektiğini düşünürler. Toplumcu gerçekçi sanatçı, her şeyden önce çevresindeki bozuklukları, düzensizlikleri, değiştirme çabasındadır. Sanatçı, eserinde gerçekçi olmanın yanı sıra müdahildir. Değiştirmek istediği sosyal hayat karşısında, bu bozukluğu oluşturan kötünün karşısında, iyininse yanında yer alır, taraf tutar. Ezilen mazlumun yanında yer alan sanatçı, zalimi ise bütün olumsuz özellikleri ile değerlendirir ve kötü yönleriyle ortaya koyar.

Kemal Bilbaşar, eserlerinin birçoğunda toplumsal gerçekçiliğin, taraf tutma ilkesini dikkate alarak oluşturduğu kişilerin yanında ya da karşısında bir tavır sergiler.

Cemo'da taraf tutma ilkesinin sonucu olarak kişiler iyi ve kötü olmak üzere sınıflandırılabilir. Eserde iyiler, hem kişilik özellikleri hem de az da olsa fiziksel özellikleri ile güzel çizilirken, kötüler bütün feodal kırıntısı tipler gibi çirkin olmanın yanı sıra bütün 
olumsuz özellikleri üzerinde taşıyan tipler olarak karşımıza çıkar.

Kahramanın kötü çizimi yazarın "yan tutma" ilkesiyle hareket ettiğinin bir göstergesidir. Aynı şekilde Bilbaşar'ın diğer bazı kahramanları tanıtırken lehte veya aleyhte tavır takındığı kolayca görülür. Ezilen, mağdur olan köylüyü çizerken de yine aynı tavrı takınır. Sömürü düzeni karşısında ağaya ses çıkarmayan saf köylüler, bu yaptıklarının sonucuna da katlanırlar. Cemo ve Memo'nun peşinden gitmeyip, ağanın emri altında çalışan köylülerin sahip olduğu tek şey karın tokluğuna yedikleri yemeklerdir. Cemo ve Memo'nun peşinden gidip ağa zulmünden kaçan bazı köylüler de yine ağanın kurduğu oyunla sahip oldukları yurtluktan olurlar. Köy halkını kulları gibi gören ağa, kendisine karşı gelmeleri durumunda ise onları öldürmeye kadar varan işkenceleri yapma hakkını kendinde hak bulur. Fakat romanın sonu trajik bir şekilde bitmez. Eser boyunca toplumcu gerçekçiliğin halka adanmış bir edebiyat ve onun sonucu olarak ezilenin yanında yer alma yani yan tutma ilkesini gözeten yazar, kötünün değil iyinin kazanmasına sebep olur. Roman sonunda Memo ve Cemo'nun Sorikoğlu'nun öldürüşü ağalık düzenine verilmiş bir cevap, bir başkaldırıdır. Yazar roman boyunca arka çıktığı, destek olduğu, karakterini romanın sonunda ezilmiş halkın intikamını alan bir savaşçıya dönüştürür. Yazar bu konuda iletisini açık bırakmıştır. Yıllarca ağalık düzenine karşı ezilen, hor görülen sömürülen halkın bir gün uyanacağına ve yapılanların hesabını ödeteceğini göstermeye çalışmıştır. Roman boyunca trajik şekilde ilerleyen saf köylünün durumu, romanın sonunda başarıya ulaşır.

\section{Sonuç}

Gerçekçilik akımının uzantısı olan toplumcu gerçekçilik, eleştirel gerçekçiliğin de devamı sayılır. Marksist anlayışın, sanata yansımış halidir toplumcu gerçekçilik. Toplumsal gerçekçiler, "sanat toplum içindir" anlayışını dikkate alarak eserlerini kaleme almışlardır. Bu açıdan konuları da yine toplumun alt kesimin yani işçi, köylü, ezilen, mağdur olan halkın yaşadıkları trajediler boyutunda seçilmiştir.

Kemal Bilbaşar, Türk edebiyatında, döneminin en önemli toplumsal gerçekçi yazarlarındandır. Eserlerinde toplumsal gerçekçiliğin etkileri açıkça görülür. Kendisi de röportajlarında, konuşmalarında bu dikkatini sık sık dile getirir. Bilbaşar'a göre sanatçı iyi olanı ifade etmelidir. Sanatçı doğru olanı yansıtmalıdır. Bilbaşar, kendi ifadesiyle "fikirde toplumcu, sanatta gerçekçi görüşüne" bağlı olduğunu söyler.

Gerçekçiliğin çeşitli yollarını deneyen Kemal Bilbaşar, Türk edebiyatında tenkitçi-sosyal gerçekçiliğin iyice anlaşılmadığı bir devirde, şartların uygun olmadığı bir zamanda bu kuramı uygulamış, verdiği eserlerde de oldukça başarılı olmuştur. Fakat bu görüşü birtakım tepkilerle karşılaşınca, yolunu daha çok yerli konulara, Anadolu kasaba gerçekliğine ve büyük şehirlerdeki küçük insanlara çevirmiştir.

Kemal Bilbaşar, çoğu eserini toplumcu gerçekçi hassasiyetle ele alır. Bilbaşar, Cemo'da açıkça ve ideolojik olarak Marksizm propagandası yapmak yerine, eserinde 
ezilen, hor görülen, sömürülen köylü ile onu ezen ağa/şeyh/seyit çatışmasına yer vermiştir.

Bilbaşar, Cemo'da ağa-kul-devlet üçgeni arasındaki ilişkiler ağı tüm çıplaklığıyla verirken, ağalık sisteminin, toplum üzerinde ne denli etkili olduğu çeşitli olaylarla anlatılmaya çalışır.

Bilbaşar, ağa-köylü çatışmasında, sanatsal ifadelerden uzak, sosyal gerçekliği vurgulamaya çalışmıştır. Bunu yaparken iyinin yanında yer alıp, onların sözcüsü konumunda hareket etmiştir. Bireysel olandan sıyrılıp, Doğu Anadolu'da kitlelerin sesi olmaya çalışmıştır. Ezen-ezilenin oluşturduğu sınıfsal çatışmada kötünün karşısında tavır alıp, iyileri adeta yönlendirerek onların kazanmasına sebep olmuştur.

\section{Notlar}

1 Yazarın, Etrafimızdaki Duvar (1941) ve Kıbrıs Ateşler Iç̧inde (1958) adlı tefrika halinde kalmış iki romanı daha vardır.

\section{Kaynaklar}

Aragon, L. (1994) Saf şiir yoktur, (Çev. E. Alkan), İstanbul: Broy

Baydar, M. (1960) Edebiyatçılarımız ne diyorlar?, İstanbul: Ahmet Halit Yaşaroğlu Kitapçılık. “Bilbaşar'la Konuşma” (1972) Yeni Ortam. nr. 96, 17 Aralı.

Çetin, N. (2004) Türk hikâyesinde sosyalist realizm (toplumcu gerçekçilik), Hece Öykü Dergisi, Ağustos / Eylül, S.2, s. 52-71

Çubukçu, A. (1996) Sosyalist gerçekçilik 1-4, Evrensel Kültür, 56: 25-40.

Fischer, E. (1974) Sanatın gerekliliği, (Çev. C. Çapan), İstanbul: Konuk.

Gülgeçgil, İ. (1976) Sanatta sosyalist gerçekçilik, İstanbul: Yeni Dünya.

Gün, S. (2013/4) Mülksüzleşme süreci bağlamında bir köy Monografisi, Folklor Edebiyat, Say1: 76 , s. 80

Jdanov, A.A. (1977) Edebiyat, müzik ve felsefe üzerine, (Çev. F. Berktay), İstanbul: Bora.

Kağan, M. (1993) Estetik ve sanat dersleri, (Çev. A. Çalışlar), Ankara: İmge.

Kemal B. (1977) Milliyet Sanat, S. 21, Ocak, s.3.

Kemal Bilbaşar Özeleştirisini Yapıyor, (1971) Yeni Edebiyat, Ağustos, s.6.

Kemal Bilbaşar Anlatıyor (1967) Türk Dili, Sayı:195, 1 Aralık, s.218-219.

Kemal Bilbaşar Diyor Ki: (1960) Yelken, Sayı:45, Ekim, s.19.

Kurdakul, Ş. (1987) Çăğdaş Türk edebiyatı II cumhuriyet dönemi (1923-1950), İstanbul:

Broy.

Lunaçarski, A. (1998) Sosyalizm ve edebiyat. (Çev. A. Bezirci). İstanbul: Evrensel.

Marx, K. (1997) Hegel'in hukuk felsefesinin eleştirisi, (Çev. K. Somer). Ankara: Sol.

Marx, K. - Engels F. (1968) Sanat ve edebiyat. (Çev. M. Belge). Yeni Dergi, S. 44.

Moran, B. (2004) Edebiyat kuramlarl ve eleştiri, İstanbul: İletişim.

Oktay, A. (2008) Toplumcu gerçekçiliğin kaynakları, İstanbul: İthaki. 
Özdemir, E. (1981) Gerçekçilik Üzerine Yargılar, Türk Dili-Yazın Akımları Özel Sayısı, s. 349.

Siniavski, A. (1967) Sosyalist realizm, (çev. S. Türker), İstanbul: Habora.

Suchkov, B. (1978) Gerçekçiliğin tarihi, (çev. A. Çalışlar), İstanbul: Bilim.

Tunalı, I.(1979) Marksist eleştiri, İstanbul: Altın Kitaplar.

Ünlü, M. - Özcan, Ö. (1991) Cumhuriyette yeniler dönemi, 1940-1960, İstanbul: İnkılap. 